\title{
Sawdust Ash as Powder Material for Self-Compacting Concrete Containing Naphthalene Sulfonate
}

\author{
Augustine U. Elinwa and Ahmed M. Mamuda \\ Civil Engineering Programme, Abubakar Tafawa Balewa University, PMB 0248, Bauchi, Nigeria \\ Correspondence should be addressed to Augustine U. Elinwa; auelinwa@gmail.com
}

Received 8 January 2014; Accepted 4 April 2014; Published 5 May 2014

Academic Editor: Rafat Siddique

Copyright ( 2014 A. U. Elinwa and A. M. Mamuda. This is an open access article distributed under the Creative Commons Attribution License, which permits unrestricted use, distribution, and reproduction in any medium, provided the original work is properly cited.

\begin{abstract}
Tests are carried out to determine the fluidity of Ashaka Portland cement paste and its compatibility with sawdust ash (SDA) as powder material for self-compacting cement (SCC) mixtures. Results of the investigation showed that saturation was achieved at w/c ratios of 0.4 and 0.42 , at dosages of naphthalene sulfonate superplasticizers of $3.5 \%$ and $2 \%$, respectively. The optimum replacement level for the SCC mixture was $10 \mathrm{wt} . \%$ of cement by SDA and 2\% of the superplasticizer dosage. The achieved spread and flow time were $26 \mathrm{~cm}$ and 8 seconds and are within the specified range of $24 \mathrm{~cm}$ to $26 \mathrm{~cm}$ and 7 to 11 seconds, respectively. Statistical inference showed that the mix, w/c, and the interaction between the mix and $\mathrm{w} / \mathrm{c}$ ratio are significant.
\end{abstract}

\section{Introduction}

Superplasticizers are often added during the mixing stage of concrete in small quantities related to the mass of cement to increase the fluidity of fresh concrete, increase strength, and prolong durability of hardened concrete. Researches have shown that compatibility of cement and superplasticizers is influenced by factors as the content of $\mathrm{C}_{3} \mathrm{~A}$ and $\mathrm{C}_{4} \mathrm{AF}$ phase in PC clinker, total alkali amount, cement fineness, and the type and the amount of calcium sulfate [1].

Compatibility problems between superplasticizers and cement have been reported and these may be characterized by the fluidity of cement paste and its loss with time [2, 3]. Superplasticizer addition decreases the yield value of the paste close to zero, but the plasticity does not decrease significantly [4]. Naphthalene sulfonate superplasticizer is often used to improve the rheology of fresh concrete [5]. Termkhajornkit and Nawa [4] have reported in their work that the surface potential of fly ash differed from ordinary Portland cement (OPC) in both sign and value, and thus this is the reason for fly ash-cement paste flocculation. When naphthalene sulfonate superplasticizer was introduced into the fly ash-cement paste, the signs were the same and therefore dispersed well due to higher potential barrier.
Adsorption of naphthalene sulfonate superplasticizers to the surface of cement particles changed the zeta potential of the particle surface to negative and thus increased the absolute value $[6,7]$.

The fluidity of sawdust ash-cement paste has not been reported. In this study, it was considered necessary to determine firstly the rheological properties of cement mortar using naphthalene sulfonate superplasticizer and secondly the influence of SDA and its compatibility on flow properties. Sawdust ash (SDA) was obtained from burning of timber wastes from the milling industries and the ash contains mainly silicates (67\%). The methods of obtaining, burning, and characterizing the SDA were fully discussed in a previous paper where it was used with concrete [8]. SDA has pozzolanic properties and is thus a promising supplementary material for concrete production.

\section{Experiment}

Figure 1 is the flow diagram used in designing the mix for the self-compacting concrete; "Ashaka" Portland cement conforming to BS 12 [9] was used. SDA obtained from thermally activated timber wastes at temperatures of between $400^{\circ} \mathrm{C}$ and $600^{\circ} \mathrm{C}$ was used [8]. The physical and chemical 


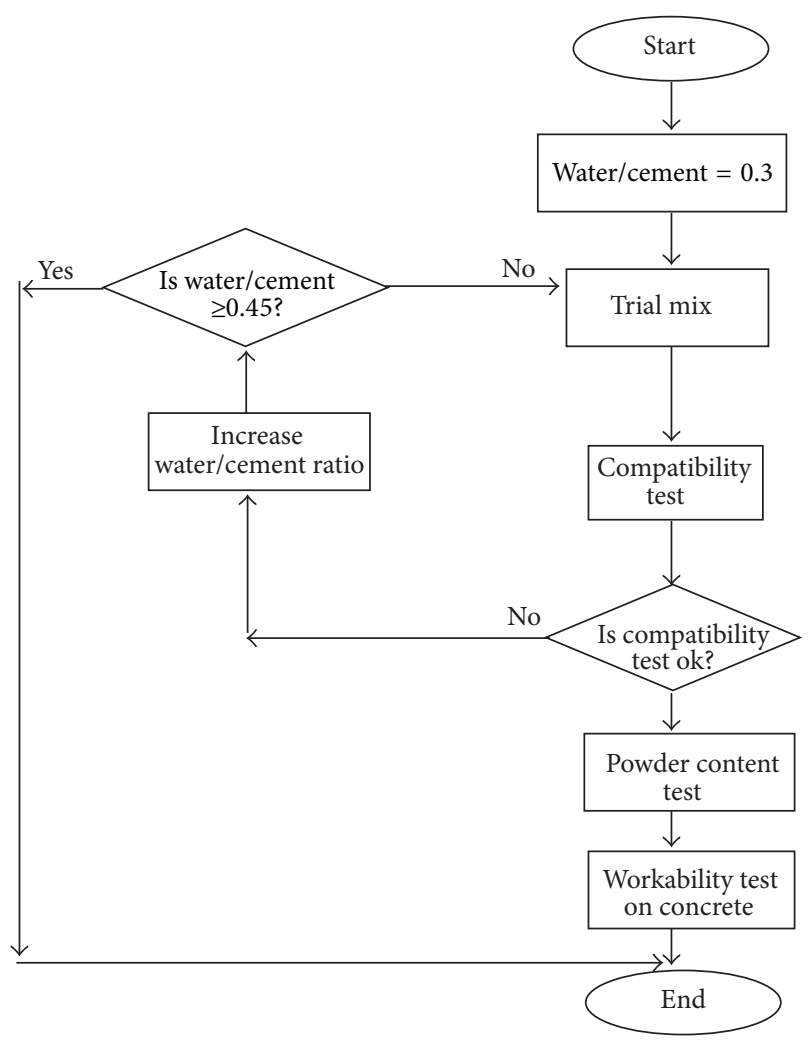

FIgURE 1: Flow diagram mix for SCC.

properties of Ashaka Portland cement and SDA are given in Table 1 . The fine aggregate is river sand with a specific gravity of 2.57 , moisture content of $14.4 \%$, and bulk density of $1472 \mathrm{~kg} / \mathrm{m}^{3}$ and falls in zone 2 in the classification table in accordance with BS 882 [10]. The superplasticizer was a commercial naphthalene sulfonate superplasticizer produced by W. R. Grace and Co., USA, named as Daracem 19. It has a specific gravity of 1.18 and $\mathrm{pH}$ of 9.5 and the dry extract by mass is $40 \%$.

2.1. Compatibility Test (Fluidity Test). Table 2 shows the mixture proportions for the compatibility test (fluidity test). The water-binder ratio of paste was from 0.3 to 0.42 . The dosage of the superplasticizer varied from 0 to $4 \mathrm{wt} . \%$ of cement. To assess the compatibility of the Portland cement with the naphthalene sulfonate superplasticizer, the standard truncated cone (Figure 2) was used to measure the flow. It has an upper inner diameter of $70 \mathrm{~mm}$, a bottom inner diameter of $100 \mathrm{~mm}$, and a height of $60 \mathrm{~mm}$. The cone was placed on a $750 \mathrm{~mm} \times 750 \mathrm{~mm}$ glass plate and filled with the sample of mortar. The upper surface of the mortar was finished with trowel and the cone was lifted vertically. The diameter of spread of the mortar after the cone was lifted was measured in two perpendicular directions $\left(d_{1}\right.$ and $\left.d_{2}\right)$, using a ruler, and the average is recorded. Results are shown in Table 3.

2.2. Powder Content Test. The powder content test was carried out immediately after saturation was achieved from
TABLE 1: Chemical and physical properties of OPC and SDA.

\begin{tabular}{|c|c|c|}
\hline Oxides & Ashaka PC & Sawdust ash \\
\hline $\mathrm{SiO}_{2}(\%)$ & 20.7 & 67.2 \\
\hline $\mathrm{Al}_{2} \mathrm{O}_{3}(\%)$ & 6.1 & 4.1 \\
\hline $\mathrm{Fe}_{2} \mathrm{O}_{3}(\%)$ & 2.3 & 2.3 \\
\hline $\mathrm{CaO}(\%)$ & 62.1 & 10.0 \\
\hline $\mathrm{MgO}(\%)$ & 1.2 & 5.8 \\
\hline $\mathrm{Na}_{2} \mathrm{O}(\%)$ & 0.9 & 0.1 \\
\hline $\mathrm{K}_{2} \mathrm{O}(\%)$ & 1.0 & 0.1 \\
\hline $\mathrm{SO}_{2}(\%)$ & 1.6 & 0.5 \\
\hline $\mathrm{P}_{2} \mathrm{O}_{5}(\%)$ & - & 0.5 \\
\hline $\mathrm{MnO}(\%)$ & - & 0.01 \\
\hline Specific gravity & 3.15 & 2.29 \\
\hline Ignition loss (\%) & 1.00 & 4.6 \\
\hline Loose bulk density $\left(\mathrm{kg} / \mathrm{m}^{3}\right)$ & 1550 & 830 \\
\hline Specific surface Blaine $\left(\mathrm{m}^{2} / \mathrm{kg}\right)$ & 355 & 151 \\
\hline Moisture content (\%) & - & 0.37 \\
\hline $\mathrm{pH}$ value & & 10.10 \\
\hline \multicolumn{3}{|c|}{ Bogue potential compound composition: } \\
\hline $\mathrm{C}_{3} \mathrm{~S}$ & 46 & \\
\hline $\mathrm{C}_{2} \mathrm{~S}$ & 24 & \\
\hline $\mathrm{C}_{3} \mathrm{~A}$ & 12 & \\
\hline $\mathrm{C}_{4} \mathrm{AF}$ & 7 & \\
\hline
\end{tabular}

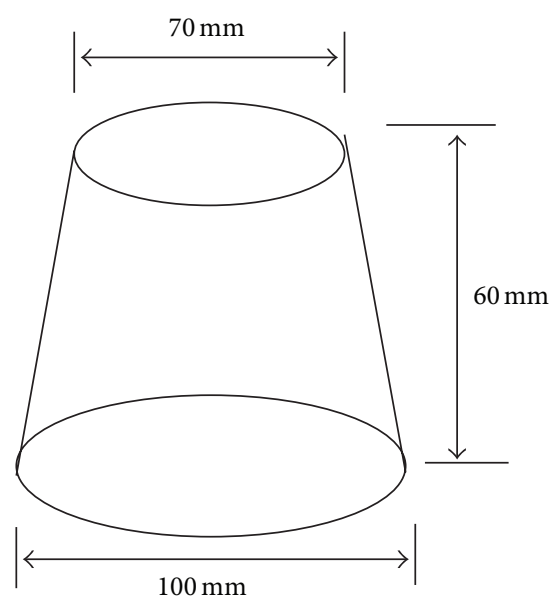

FIGURE 2: Mortar spread cone for compatibility test.

the compatibility (fluidity) test. This was done using the flow and V-Funnel tests (Figure 3). The mixture proportions for the test are shown in Table 4. The optimum dosage of $2 \%$ naphthalene sulfonate superplasticizer and cement content of $479 \mathrm{~kg} / \mathrm{m}^{3}$ were used at a w/c ratio of 0.42 . These were values at the saturation point from the compatibility (fluidity) test. The replacement ratios of SDA in the powder content test varied from 0 to $20 \mathrm{wt} . \%$ of cement. A total of 5 mixes were used (PC-01N to PC-05N). PC-01N was the control mix containing NS with no SDA (powder material), while PC-05N was containing SDA of $20 \mathrm{wt} . \%$ of cement as replacement. The letter $\mathrm{P}$ signifies the powder material. Two 
TABLE 2: Mix proportions for the compatibility test.

\begin{tabular}{|c|c|c|c|c|c|c|}
\hline SP type & Mix number & SP dosage (\%) & Cement $\left(\mathrm{kg} / \mathrm{m}^{3}\right)$ & Sand $\left(\mathrm{kg} / \mathrm{m}^{3}\right)$ & Water $\left(\mathrm{kg} / \mathrm{m}^{3}\right)$ & Water-cement \\
\hline \multirow{11}{*}{ NS } & M-01A & 0.0 & 508.57 & 762.86 & 152.59 & 0.3 \\
\hline & $\mathrm{M}-02 \mathrm{~A}$ & 4.04 & 508.57 & 762.86 & 152.59 & 0.3 \\
\hline & M-03A & 8.07 & 508.57 & 762.86 & 152.59 & 0.3 \\
\hline & M-04A & 12.11 & 508.57 & 762.86 & 152.59 & 0.3 \\
\hline & M-05A & 16.14 & 508.57 & 762.86 & 152.59 & 0.3 \\
\hline & M-06A & 20.18 & 508.57 & 762.86 & 152.59 & 0.3 \\
\hline & M-07A & 24.22 & 508.57 & 762.86 & 152.59 & 0.3 \\
\hline & M-08A & 28.25 & 508.57 & 762.86 & 152.59 & 0.3 \\
\hline & M-09A & 32.29 & 508.57 & 762.86 & 152.59 & 0.3 \\
\hline & M-10A & 36.32 & 508.57 & 762.86 & 152.59 & 0.3 \\
\hline & $\mathrm{M}-11 \mathrm{~A}$ & 40.36 & 508.57 & 762.86 & 152.59 & 0.3 \\
\hline \multirow{11}{*}{ NS } & M-01B & 0.0 & 484.03 & 762.86 & 152.59 & 0.4 \\
\hline & M-02B & 3.84 & 484.03 & 762.86 & 152.59 & 0.4 \\
\hline & M-03B & 7.69 & 484.03 & 762.86 & 152.59 & 0.4 \\
\hline & M-04B & 11.53 & 484.03 & 762.86 & 152.59 & 0.4 \\
\hline & M-05B & 15.38 & 484.03 & 762.86 & 152.59 & 0.4 \\
\hline & M-06B & 19.22 & 484.03 & 762.86 & 152.59 & 0.4 \\
\hline & M-07B & 23.06 & 484.03 & 762.86 & 152.59 & 0.4 \\
\hline & M-08B & 26.91 & 484.03 & 762.86 & 152.59 & 0.4 \\
\hline & M-09B & 30.75 & 484.03 & 762.86 & 152.59 & 0.4 \\
\hline & M-10B & 34.60 & 484.03 & 762.86 & 152.59 & 0.4 \\
\hline & M-11B & 38.44 & 484.03 & 762.86 & 152.59 & 0.4 \\
\hline \multirow{14}{*}{ NS } & M-01C & 0.00 & 479.39 & 762.86 & 152.59 & 0.42 \\
\hline & M-02C & 1.92 & 479.39 & 762.86 & 152.59 & 0.42 \\
\hline & M-03C & 3.84 & 479.39 & 762.86 & 152.59 & 0.42 \\
\hline & M-04C & 5.75 & 479.39 & 762.86 & 152.59 & 0.42 \\
\hline & M-05C & 7.67 & 479.39 & 762.86 & 152.59 & 0.42 \\
\hline & M-06C & 9.59 & 479.39 & 762.86 & 152.59 & 0.42 \\
\hline & M-07C & 11.51 & 479.39 & 762.86 & 152.59 & 0.42 \\
\hline & M-08C & 13.43 & 479.39 & 762.86 & 152.59 & 0.42 \\
\hline & M-09C & 15.34 & 479.39 & 762.86 & 152.59 & 0.42 \\
\hline & M-10C & 17.26 & 479.39 & 762.86 & 152.59 & 0.42 \\
\hline & $\mathrm{M}-11 \mathrm{C}$ & 19.18 & 479.39 & 762.86 & 152.59 & 0.42 \\
\hline & $\mathrm{M}-12 \mathrm{C}$ & 21.10 & 479.39 & 762.86 & 152.59 & 0.42 \\
\hline & M-13C & 23.02 & 479.39 & 762.86 & 152.59 & 0.42 \\
\hline & M-14C & 24.93 & 479.39 & 762.86 & 152.59 & 0.42 \\
\hline
\end{tabular}

tests were carried out for each replacement level and the average is recorded. Results are shown in Table 5.

\section{Results and Discussions}

SDA is a latent hydraulic material and contains approximately $67 \%$ of silicates. It needs more water for consistency and when added to cement it triggers off a pozzolanic reaction with the excess $\mathrm{Ca}(\mathrm{OH})_{2}$ produced during the cement hydration. Thus, SDA deferred the hydration of the paste and extends the setting time [9]. Unburned carbon $(<5 \%)$ has been identified to affect the amount of adsorption of superplasticizers [4]; therefore, the ignition loss of SDA was kept under $4.6 \%$ and thus the effect of unburned carbon in this work was neglected.
The fluidity test results are shown in Figures 4(a)4(c). The relationships between the rheologies of mortar at different dosages of superplasticizer are quite parallel. The compatibility (fluidity) at w/c ratio of 0.3 (Figure $4(a)$ ) increased with the increase in the dosage of NS without showing any saturation point. However, at $0.4 \mathrm{w} / \mathrm{c}$ ratio (Figure 4(b)), the fluidity also increased but saturation was achieved at a dosage of approximately $3.5 \%$. At the w/c ratio of 0.42 (Figure $4(\mathrm{c})$ ), the fluidity of the mortar did not increase significantly at $2 \%$ dosage. The flow diameter at this dosage is $28 \mathrm{~cm}$. This is the saturation point and $2 \%$ is the threshold dosage. It can be said that the code requirements for SCC materials are satisfied by these values [11]. 
TABLE 3: Compatibility test results.

\begin{tabular}{|c|c|c|c|}
\hline Mix number & $\mathrm{W} / \mathrm{C}$ ratio & SP dosage (\%) & Flow diameter $(\mathrm{mm})$ \\
\hline $\mathrm{M}-01 \mathrm{~A}$ & \multirow{11}{*}{0.3} & 0.0 & 12.75 \\
\hline $\mathrm{M}-02 \mathrm{~A}$ & & 4.04 & 13.50 \\
\hline M-03A & & 8.07 & 15.25 \\
\hline $\mathrm{M}-04 \mathrm{~A}$ & & 12.11 & 17.00 \\
\hline M-05A & & 16.14 & 17.75 \\
\hline M-06A & & 20.18 & 19.50 \\
\hline M-07A & & 24.22 & 20.00 \\
\hline M-08A & & 28.25 & 21.00 \\
\hline M-09A & & 32.29 & 21.50 \\
\hline $\mathrm{M}-10 \mathrm{~A}$ & & 36.32 & 22.75 \\
\hline $\mathrm{M}-11 \mathrm{~A}$ & & 40.36 & 23.50 \\
\hline M-01B & \multirow{11}{*}{0.4} & 0.0 & 14.75 \\
\hline M-02B & & 3.84 & 16.00 \\
\hline M-03B & & 7.69 & 17.25 \\
\hline M-04B & & 11.53 & 17.75 \\
\hline M-05B & & 15.38 & 19.50 \\
\hline M-06B & & 19.22 & 20.25 \\
\hline M-07B & & 23.06 & 21.75 \\
\hline M-08B & & 26.91 & 23.50 \\
\hline M-09B & & 30.75 & 25.75 \\
\hline M-10B & & 34.60 & 27.50 \\
\hline M-11B & & 38.44 & 27.50 \\
\hline M-01C & \multirow{14}{*}{0.42} & 0.00 & 18.75 \\
\hline $\mathrm{M}-02 \mathrm{C}$ & & 1.92 & 19.50 \\
\hline M-03C & & 3.84 & 20.50 \\
\hline M-04C & & 5.75 & 21.50 \\
\hline M-05C & & 7.67 & 22.25 \\
\hline M-06C & & 9.59 & 23.00 \\
\hline M-07C & & 11.51 & 23.50 \\
\hline M-08C & & 13.43 & 24.50 \\
\hline M-09C & & 15.34 & 26.00 \\
\hline M-10C & & 17.26 & 26.50 \\
\hline M-11C & & 19.18 & 28.00 \\
\hline M-12C & & 21.10 & 28.00 \\
\hline M-13C & & 23.02 & 28.00 \\
\hline M-14C & & 24.93 & 28.00 \\
\hline
\end{tabular}

Workability period is determined by the interaction of the powder materials and the admixture [12]. Figure 5 shows the graph of replacement levels against flow and time for SDA mixes (PC-01N to PC-05N). The flow decreased as the percentage replacement increased. The time to achieve such flow also increased. An explanation to such behaviour can be derived from the works of Termkhajornkit and Nawa [4] on fly ash. Table 6 shows the value of the zeta potentials and flow in the system as reported by Termkhajornkit and Nawa [4]. It is seen that when the system contained no superplasticizer, the zeta potential of OPC had an opposite charge from that of the fly ash. This encouraged flocculation. It means that the total potential energy of cement particle and fly ash particle became lower than those between OPC particles. The reverse

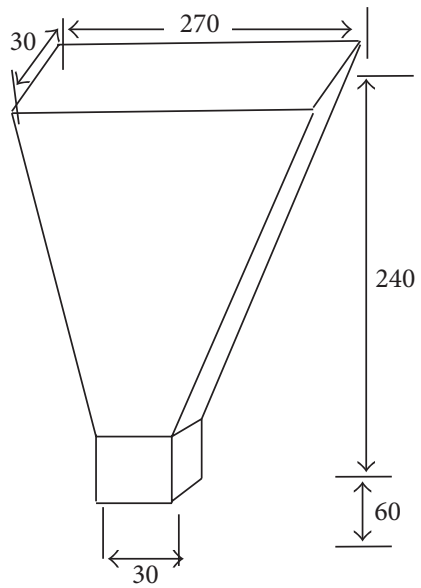

FIgURE 3: Mortar V-Funnel for powder content test.

was the case when superplasticizer was applied. The charges were the same and thus there was repulsion and improvement in the flow. SDA can be classified as a class $C$ fly ash and thus the same reasons can be adduced for the behaviour of SDA mixtures without and with naphthalene sulfonate. The stipulation by the code [11] for the mix that passed the test for SCC must be a mix that has a spread diameter of $24 \mathrm{~cm}$ to $26 \mathrm{~cm}$ and also a flow time of $7 \mathrm{sec}$ to $11 \mathrm{sec}$. From the table on the results of the powder content test, the mix that satisfied both conditions was PC-03N, which was the mix that contained $10 \%$ replacement of cement with naphthalene sulfonate superplasticizer.

\section{Statistical Analysis}

4.1. Compatibility Test (Fluidity Test). Table 7 lists the coefficients of the independent variables with their respective standard deviation (SD), value of the rate $T(t)$, and probability $(P)$, and the value of $T$ indicates the significance of the variable in the model corresponding to the probability $(P)$. If the value of $P$ is lower than or equal to $5 \%(P \leq 0.05)$, the variable is accepted as significant at a level of $5 \%$. An analysis of Table 7 shows that only the independent variables water-cement ratio (w/c) and dosage of the naphthalene sulfonate present values of $P$ lower than 5\%; hence, the remaining variable (replication) is not statistically significant. The standard deviation $(s)$ is 1.25 , coefficient of correlation $\left(R^{2}\right)=93 \%$, and $\left(R^{2}\right)$ adj $=92.8 \%$. The regression equation is as follows: flow $=8.11+3.38 \mathrm{w} / \mathrm{c}+1.13$ dosages .

Table 8 presents the analysis of variance, degree of freedom (DF), sum of squares (SS), mean squares (MD), $F_{\text {test }}$ $(F)$, and probability $(P)$. The $F_{\text {test }}$ statistically proves the existence of regression at significance level of $5 \%$. The degrees of freedom of the regression and the residual error are, respectively, 3 and 128. Figure 6 presents the graph of residues as a function of the adjusted values. This graph shows that the variance is constant; that is, the points are dispersed uniformly around zero. 


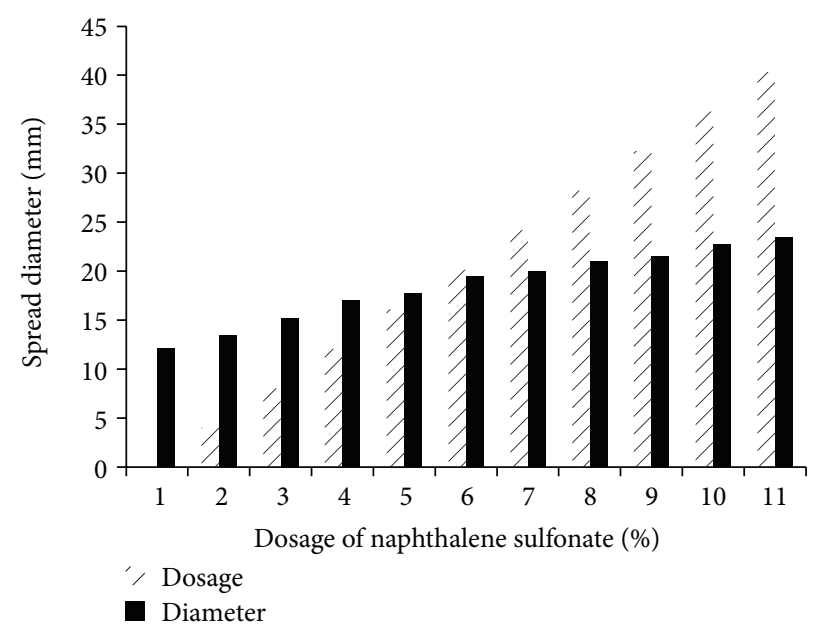

(a) $\mathrm{W} / \mathrm{C}=0.3$

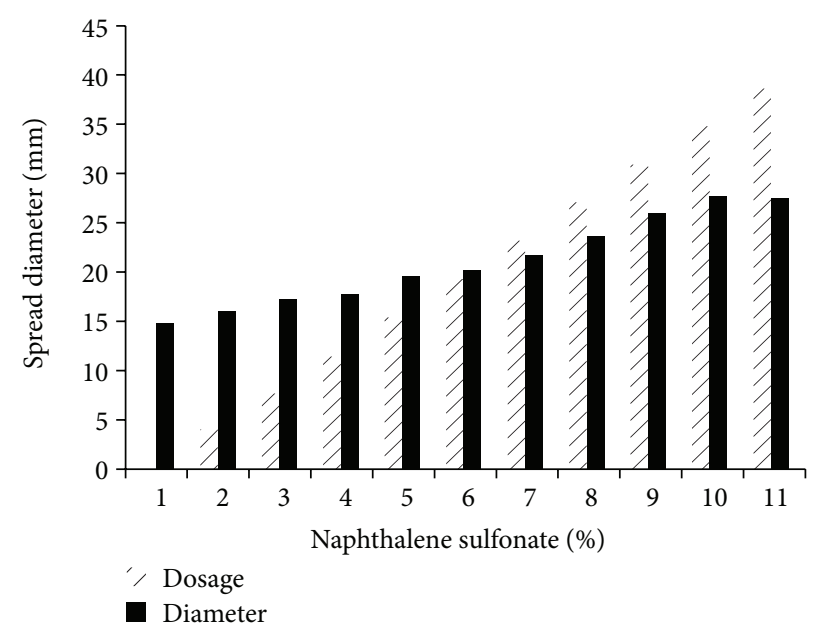

(b) $\mathrm{W} / \mathrm{C}=0.4$

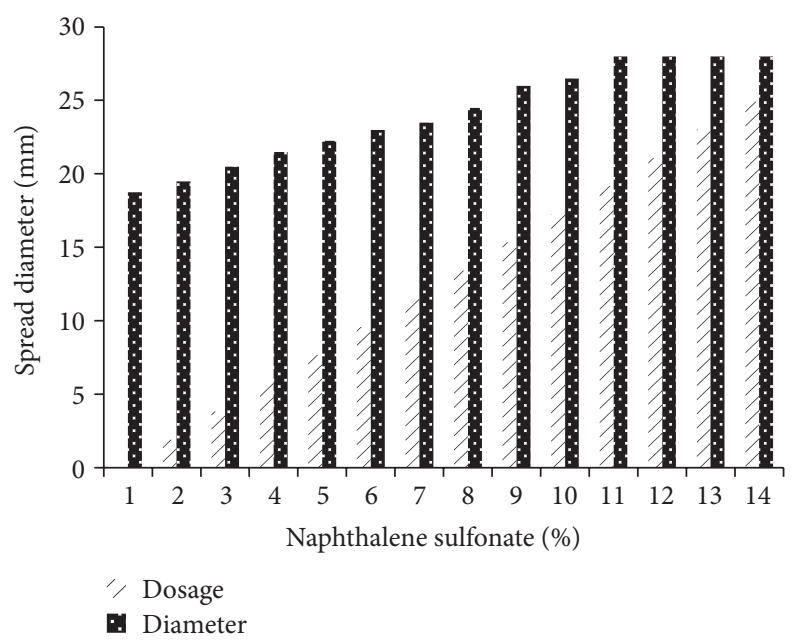

(c) $\mathrm{W} / \mathrm{C}=0.42$

FIGURE 4: Compatibility of cement with naphthalene sulfonate.

TABLE 4: Mixture proportions for the powder content test.

\begin{tabular}{cccccccc}
\hline SP type & Mix number & Cement $\left(\mathrm{kg} / \mathrm{m}^{3}\right)$ & SDA $(\%)$ & Sand $\left(\mathrm{kg} / \mathrm{m}^{3}\right)$ & Water $\left(\mathrm{kg} / \mathrm{m}^{3}\right)$ & SP dosage $(\%)$ & Water-cement ratio \\
\hline \multirow{4}{*}{ NS } & PC-01N (control) & 479 & 0 & 719 & 201 & 2.0 & 0.42 \\
& PC-02N & 445 & 5 & 719 & 201 & 2.0 & 0.42 \\
& PC-03N & 431 & 10 & 719 & 201 & 2.0 & 0.42 \\
& PC-04N & 407 & 15 & 719 & 201 & 2.0 & 0.42 \\
& PC-05N & 384 & 20 & 719 & 201 & 2.0 & 0.42 \\
\hline
\end{tabular}

TABle 5: Powder content results.

\begin{tabular}{|c|c|c|c|c|c|}
\hline \multirow{2}{*}{ SP type } & \multirow{2}{*}{ Mix number } & \multirow{2}{*}{ Powder content-SDA (\%) } & \multicolumn{2}{|c|}{ Test } & \multirow{2}{*}{ Water-cement ratio } \\
\hline & & & Mortar spread $(d)(\mathrm{cm})$ & V-Funnel $t$ (sec) & \\
\hline \multirow{5}{*}{ NS } & PC-01N & 0 & 26.0 & 4.5 & \multirow{5}{*}{0.42} \\
\hline & PC- $02 \mathrm{~N}$ & 5 & 24.8 & 6.5 & \\
\hline & PC-03N & 10 & 24.1 & 8.0 & \\
\hline & PC- $04 \mathrm{~N}$ & 15 & 22.5 & 11.5 & \\
\hline & PC-05N & 20 & 20.2 & 18.0 & \\
\hline
\end{tabular}


TABLE 6: Zeta potential and flow value in the system (Termkhajornkit and Nawa (2004) [4]).

\begin{tabular}{lccc}
\hline Kind of powder & SP & Average zeta potential $(\mathrm{mV})$ & Flow value $(\mathrm{mm})$ \\
\hline OPC & & 2.17 & 6.5 \\
MS/BA & -14.6 & 168 \\
UL/BA $^{*}$ & None & -21.1 & 115 \\
\hline OPC & & -28.4 & - \\
MS/BA & & -48.6 & - \\
UL/BA $^{*}$ & Yes & -63.3 & - \\
\hline
\end{tabular}

*Type of fly ash.

TABLE 7: Regression analysis on fluidity results.

\begin{tabular}{lcccr}
\hline Predictor & Coefficient & SD & $T$ & $P$ \\
\hline Constant & 8.1076 & 0.3572 & 22.70 & 0.000 \\
W/C & 3.3750 & 0.1344 & 25.12 & 0.000 \\
Dosage & 1.13485 & 0.03469 & 32.71 & 0.000 \\
\hline
\end{tabular}

$S=1.260 ; R$-sq $=93.0 \% ; R$-sq $($ adj $)=92.8 \%$.

TABLE 8: Balanced ANOVA on fluidity results.

\begin{tabular}{|c|c|c|c|c|c|}
\hline Source & DF & SS & MS & $F$ & $P$ \\
\hline $\mathrm{W} / \mathrm{C}$ & 2 & 1029.742 & 514.871 & 2462.06 & 0.000 \\
\hline Dosage & 10 & 1737.669 & 173.767 & 830.93 & 0.000 \\
\hline Replication & 3 & 0.424 & 0.141 & 0.68 & 0.569 \\
\hline $\mathrm{W} / \mathrm{C} *$ dosage & 20 & 119.424 & 5.971 & 28.55 & 0.000 \\
\hline Error & 96 & 20.076 & 0.209 & & \\
\hline Total & 131 & 2907.333 & & & \\
\hline
\end{tabular}

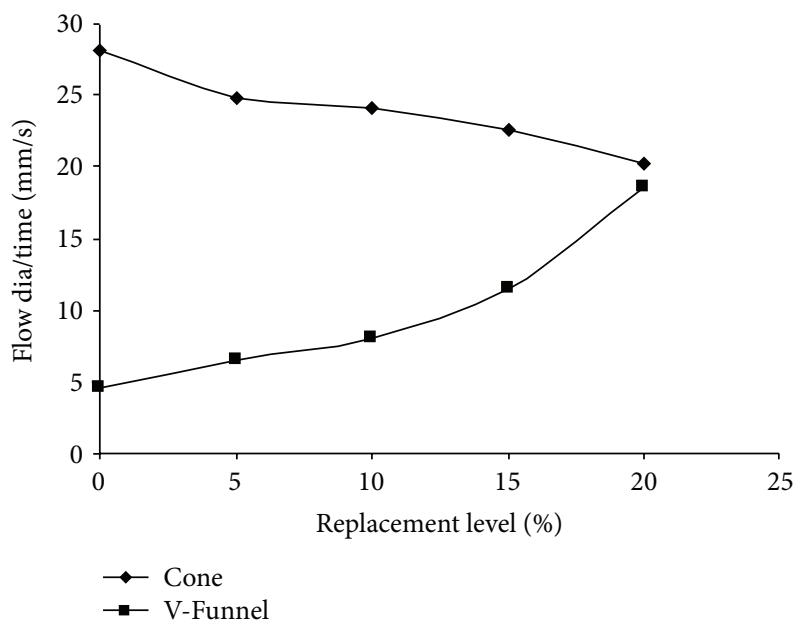

Figure 5: Flow/time for powder content test.

The test of normality of the residues shown in Figure 7 shows that the residues and, hence, the response follow a normal distribution.

4.2. Power Content Test. The statistical analysis for the two tests (spread and V-Funnel time), carried out for the power content test, shows that the mix and the constant in the

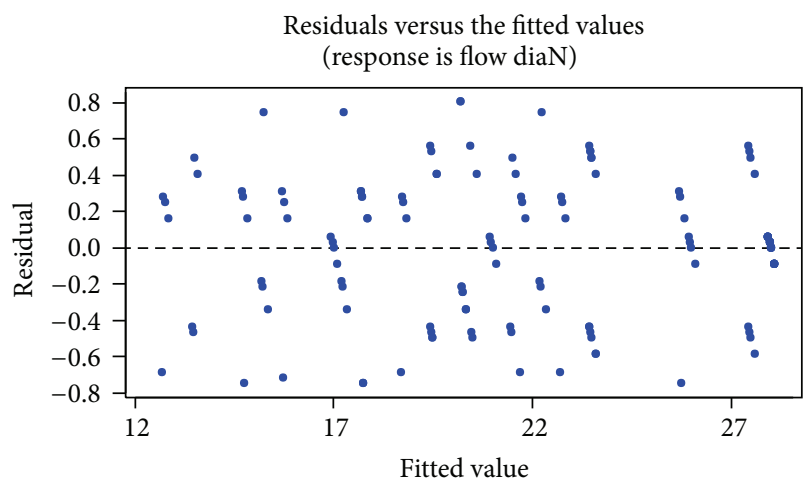

Figure 6

regression analysis are significant for the spread, while for $\mathrm{V}$ Funnel the mix only is significant. These are shown in Tables $9,10,11$, and 12 . They can be represented, respectively, by spread $=29.1-1.78 \mathrm{mix}$ and time $=0.10+3.70 \mathrm{mix}$ with $\mathrm{R}^{2}=$ $94 \%$ and $90.6 \%$, respectively. The normality and residual plots are shown in the figures.

\section{Conclusions}

Based on the results of the present investigation, the following conclusions can be drawn. 
TABLE 9: Regression analysis on table spread.

\begin{tabular}{lcccc}
\hline Predictor & Coefficient & SD & $T$ & $P$ \\
\hline Constant & 29.0750 & 0.4967 & 58.53 & 0.000 \\
Mix & -1.7750 & 0.1084 & -16.37 & 0.000 \\
Repl. & 0.0700 & 0.1371 & 0.51 & 0.616 \\
\hline
\end{tabular}

$S=0.6856 ; R-\mathrm{Sq}=94.0 \% ; R-\mathrm{Sq}(\operatorname{adj})=93.3 \%$.

TABLE 10: Analysis of variance of table spread.

\begin{tabular}{lccccc}
\hline Source & DF & SS & MS & $F$ & $P$ \\
\hline Regression & 2 & 126.148 & 63.074 & 134.20 & 0.000 \\
Error & 17 & 7.990 & 0.470 & \\
\hline Total & 19 & 134.138 & & \\
\hline
\end{tabular}

TABLE 11: Regression analysis on V-Funnel time.

\begin{tabular}{lcccr}
\hline Predictor & Coefficient & SD & $T$ & $P$ \\
\hline Constant & -0.200 & 2.096 & -0.10 & 0.927 \\
Mix & 3.2000 & 0.3891 & 8.22 & 0.000 \\
Repl. & 0.200 & 1.101 & 0.18 & 0.861 \\
\hline
\end{tabular}

$S=1.740 ; R-S q=90.6 \% ; R-S q($ adj $)=87.9 \%$.

TABLE 12: Analysis of variance on the V-Funnel spread.

\begin{tabular}{lccccc}
\hline Source & DF & SS & MS & $F$ & $P$ \\
\hline Regression & 2 & 204.90 & 102.45 & 33.83 & 0.000 \\
Error & 7 & 21.20 & 3.03 & \\
\hline
\end{tabular}

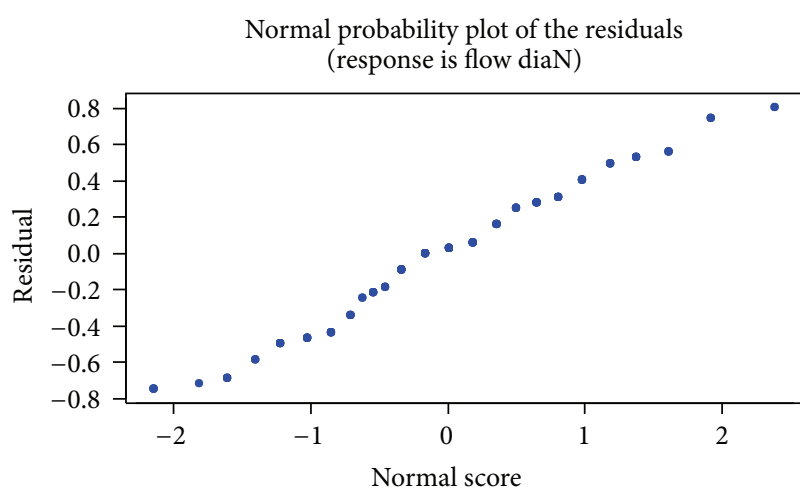

Figure 7

(i) The optimum superplasticizer dosage of $2 \%$ and cement content of $417 \mathrm{~kg} / \mathrm{m}^{3}$ with a w/c ratio of 0.42 achieved saturation and meet the code's specifications.

(ii) Saturation was also achieved at $0.4 \mathrm{w} / \mathrm{c}$ ratio but with an approximate dosage of $3.5 \%$ which did not meet the code's specifications.

(iii) It can be inferred that SDA has the same zeta potential with class $\mathrm{C}$ fly ash. (iv) The mix that passed the SCC test is the mix with $10 \%$ replacement of cement and containing $2 \%$ naphthalene sulfonate superplasticizer.

(v) The statistical analysis on fluidity shows that both $\mathrm{w} / \mathrm{c}$ and dosage are significant with $R^{2}=93 \%$ and $R^{2}$ adj $=92.8 \%$. The regression equation is given as follows: flow diameter $=8.11+3.38 \mathrm{w} / \mathrm{c}+1.13$ dosage.

(vi) The effects of both the $w / c$ and dosage are additive.

\section{Conflict of Interests}

The authors declare that there is no conflict of interests regarding the publication of this paper.

\section{References}

[1] Z. Ding, D. Zhang, and R. Yu, "High strength composite cement," China Building Material Science Technology, vol. 1, pp. 14-17, 1999.

[2] W. Qin, "Research on compatibility of cement-superplasticizer and its test method'”' Concrete, vol. 2, pp. 11-17, 1996.

[3] A. U. Elinwa and G. U. Amajuoyi, "Quarry dust as fines and the compatibility of caustic-type admixture with Ashaka cement," Nigerian Society of Engineers Technical Transaction, vol. 28, no. 3, pp. 15-19, 1993. 
[4] P. Termkhajornkit and T. Nawa, "The fluidity of fly ashcement paste containing naphthalene sulfonate superplasticizer," Cement and Concrete Research, vol. 34, no. 6, pp. 10171024, 2004.

[5] T. Nawa, T. Izumi, and Y. Edamatsu, "State-of-the-art report on materials and design of self-compacting concrete," in International Workshop on Self-Compacting Concrete, pp. 160-190, 1998.

[6] V. S. Ramachandran et al., Properties and Application in Concrete, Minister of Public Works and Government Services, Canada, 1998.

[7] E. Sakai et al., "Mechanisms of superplastification," Material Science Concrete, vol. 4, pp. 91-111, 1995.

[8] A. U. Elinwa and Y. A. Mahmood, "Ash from timber waste as cement replacement material," Cement and Concrete Composites, vol. 24, no. 2, pp. 219-222, 2002.

[9] BS 12, Specification for Portland Cement, British Standard Institution, 1996.

[10] BS 882: Part 2, Specification of Aggregates, British Standard Institution, 1973.

[11] EFNARC, Specification and Guidelines for Self-Compacting Concrete, EFNARC Publication, London, UK, 2002.

[12] S. Kordts and W. B. Düsseldorf, "Beurteilung der frischbetoneigenschaften von selbstverdichtendem beton," Beton, vol. 49, no. 4, pp. 113-123, 1999. 

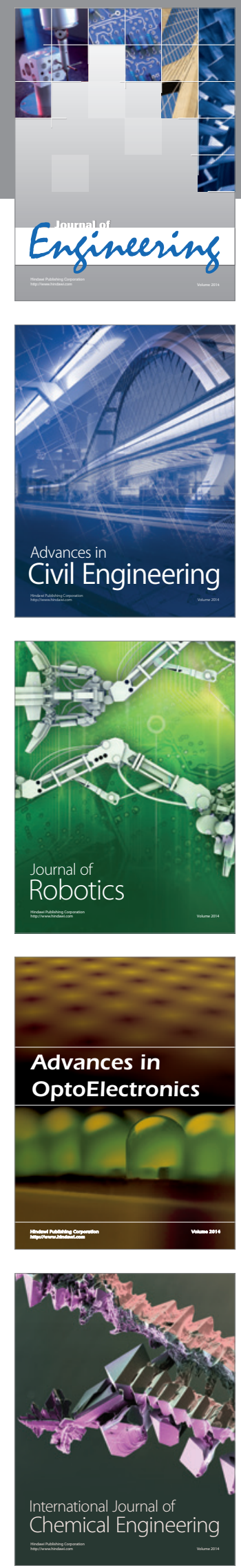

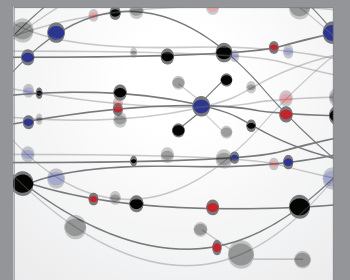

The Scientific World Journal
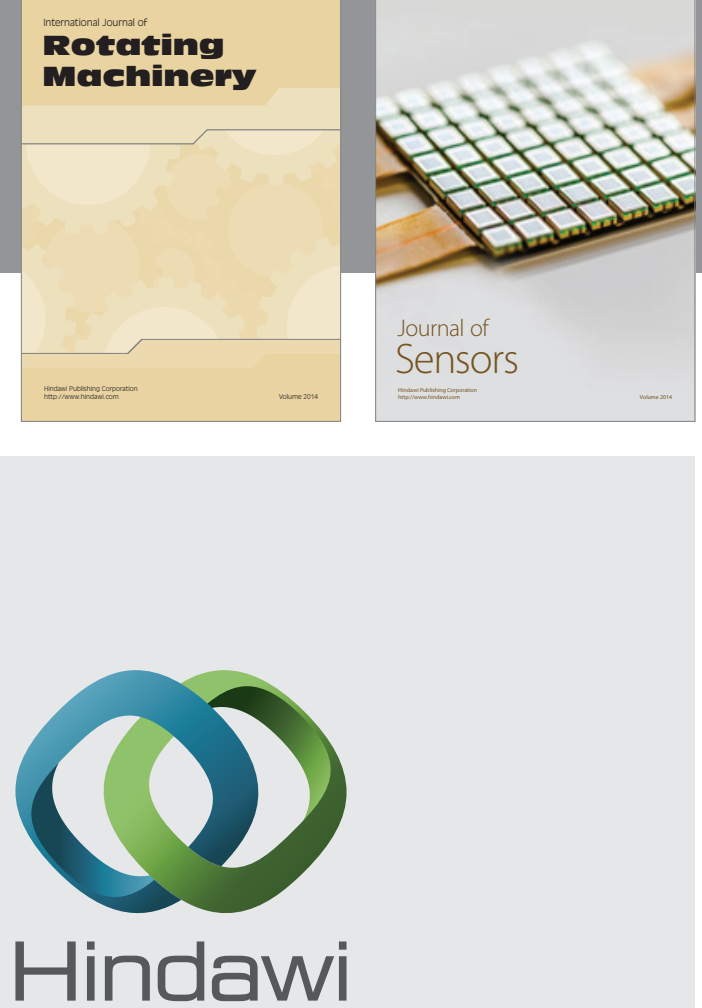

Submit your manuscripts at http://www.hindawi.com
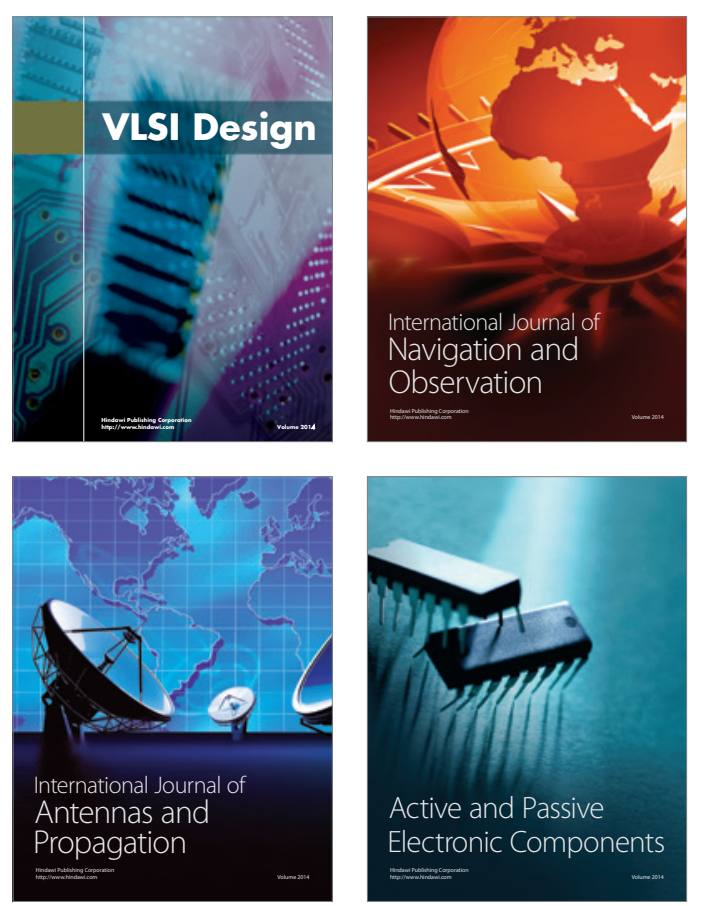
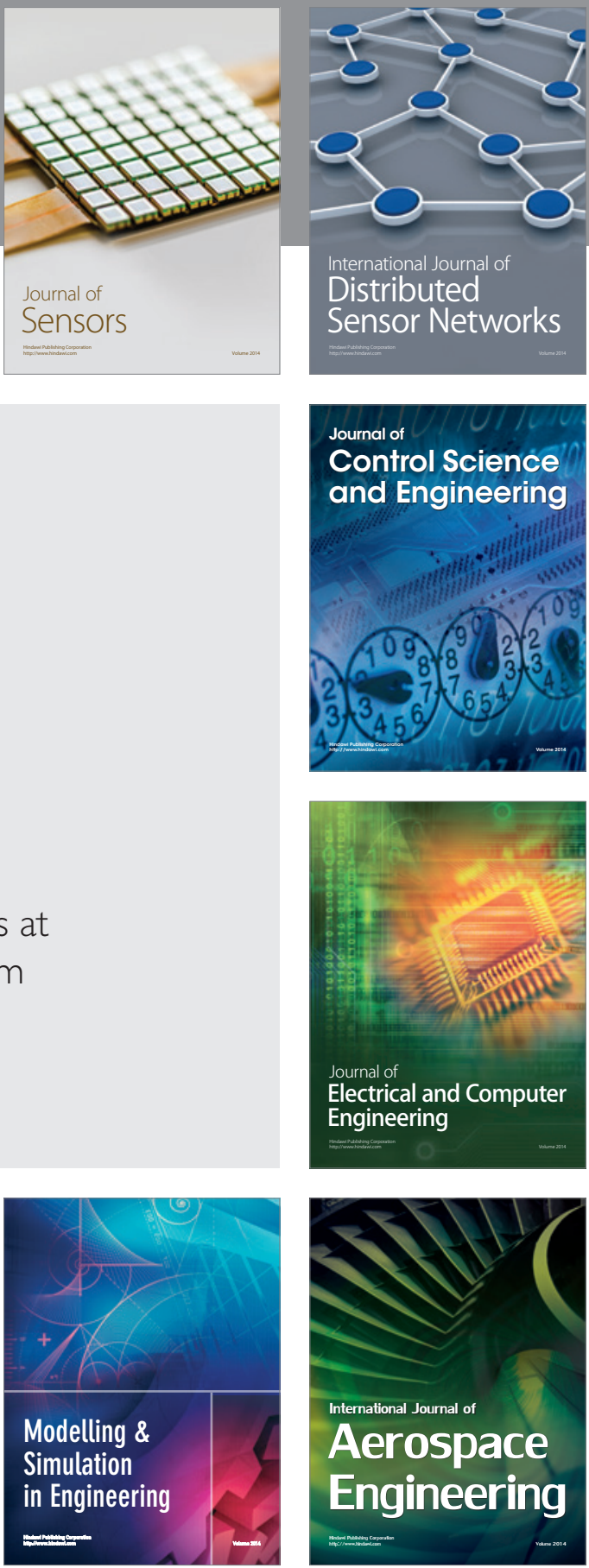

Journal of

Control Science

and Engineering
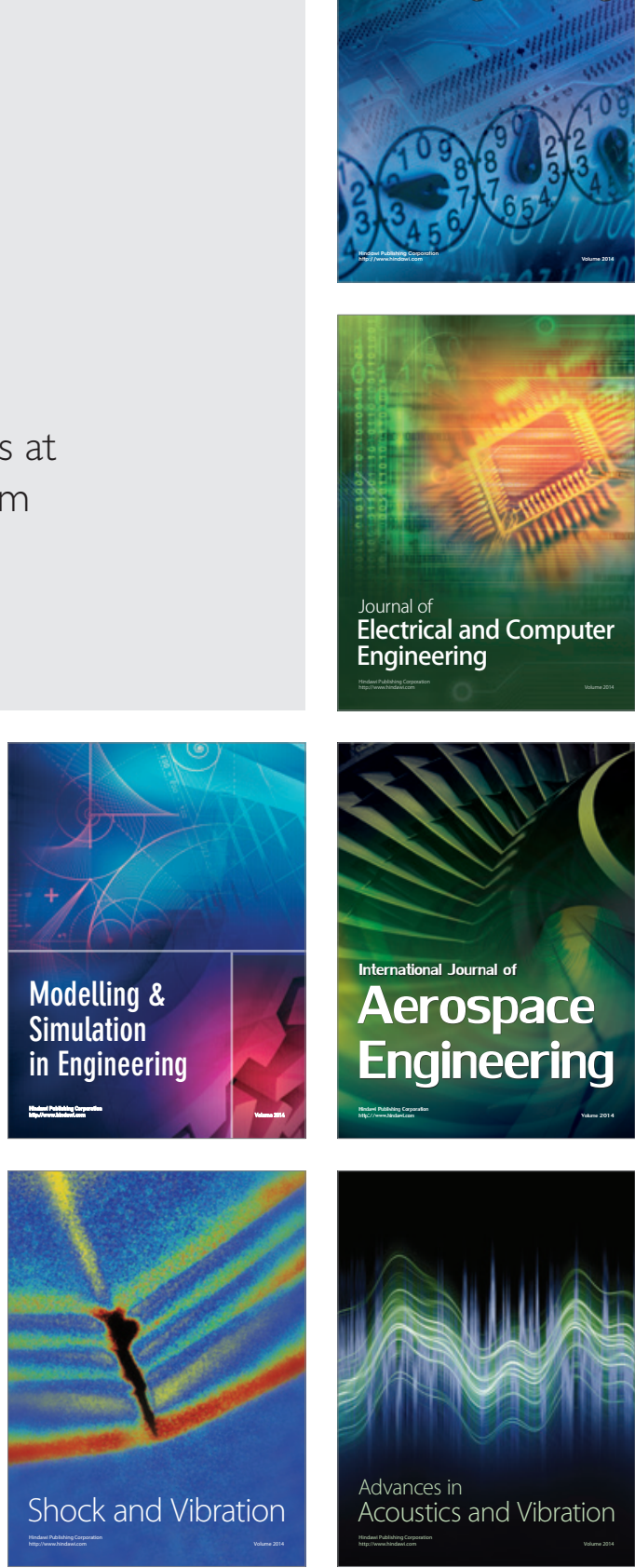